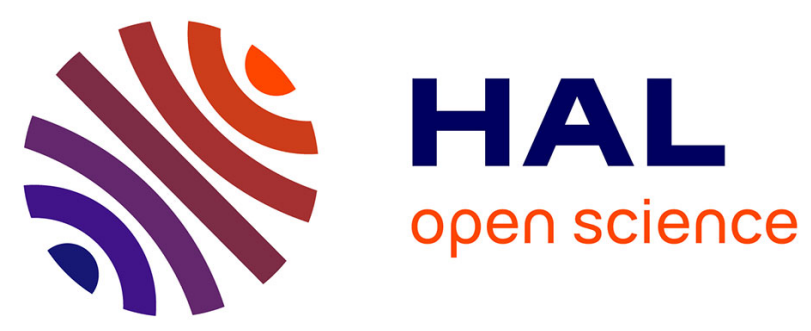

\title{
Focus groups and ecological practices: a psychosocial approach
}

Sabine Caillaud, Nikos Kalampalikis

\section{To cite this version:}

Sabine Caillaud, Nikos Kalampalikis. Focus groups and ecological practices: a psychosocial approach. Qualitative Research in Psychology, 2013, 10 (4). halshs-01206506

\section{HAL Id: halshs-01206506 https://shs.hal.science/halshs-01206506}

Submitted on 10 Jul 2017

HAL is a multi-disciplinary open access archive for the deposit and dissemination of scientific research documents, whether they are published or not. The documents may come from teaching and research institutions in France or abroad, or from public or private research centers.
L'archive ouverte pluridisciplinaire HAL, est destinée au dépôt et à la diffusion de documents scientifiques de niveau recherche, publiés ou non, émanant des établissements d'enseignement et de recherche français ou étrangers, des laboratoires publics ou privés. 
This article was downloaded by: [Universitaire De Lausanne]

On: 24 J une 2013, At: 14:51

Publisher: Routledge

Informa Ltd Registered in England and Wales Registered Number: 1072954 Registered office: Mortimer House, 37-41 Mortimer Street, London W1T 3J H, UK

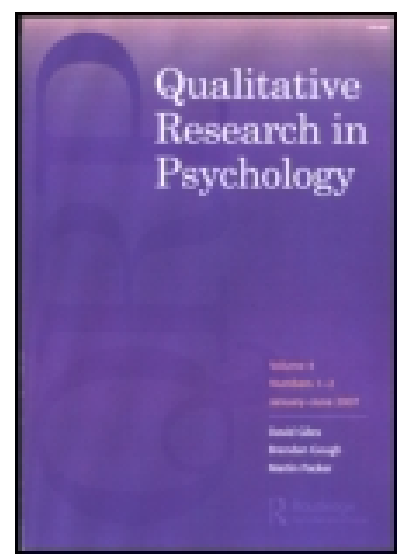

\title{
Qualitative Research in Psychology
}

Publication details, including instructions for authors and subscription information:

http:// www.tandfonline.com/ loi/ uqrp20

\section{Focus Groups and Ecological Practices: A Psychosocial Approach}

\author{
Sabine Caillaud ${ }^{a} \&$ Nikos Kalampalikis ${ }^{b}$ \\ ${ }^{a}$ Laboratoire de Psychologie des Menaces Sociales et \\ Environnementales, University Paris Descartes, Institute of \\ Psychology, Boulogne-Billancourt, France \\ ${ }^{b}$ University Lyon 2, Social Psychology Research Group (GRePS, EA \\ 4163), Institute of Psychology, Bron, France \\ Accepted author version posted online: $26 \mathrm{~J}$ an 2013. Published \\ online: $20 \mathrm{~J}$ un 2013.
}

To cite this article: Sabine Caillaud \& Nikos Kalampalikis (2013): Focus Groups and Ecological Practices: A Psychosocial Approach, Qualitative Research in Psychology, 10:4, 382-401

To link to this article: http:// dx. doi.org/ 10.1080/ 14780887.2012.674176

\section{PLEASE SCROLL DOWN FOR ARTICLE}

Full terms and conditions of use: http://www.tandfonline.com/page/terms-and-conditions

This article may be used for research, teaching, and private study purposes. Any substantial or systematic reproduction, redistribution, reselling, loan, sub-licensing, systematic supply, or distribution in any form to anyone is expressly forbidden.

The publisher does not give any warranty express or implied or make any representation that the contents will be complete or accurate or up to date. The accuracy of any instructions, formulae, and drug doses should be independently verified with primary sources. The publisher shall not be liable for any loss, actions, claims, proceedings, demand, or costs or damages whatsoever or howsoever caused arising directly or indirectly in connection with or arising out of the use of this material. 


\title{
Focus Groups and Ecological Practices: A Psychosocial Approach
}

\author{
SABINE CAILLAUD ${ }^{1}$ AND NIKOS KALAMPALIKIS ${ }^{2}$ \\ ${ }^{1}$ Laboratoire de Psychologie des Menaces Sociales et Environnementales, Univ- \\ ersity Paris Descartes, Institute of Psychology, Boulogne-Billancourt, France \\ ${ }^{2}$ University Lyon 2, Social Psychology Research Group (GRePS, EA 4163), \\ Institute of Psychology, Bron, France
}

\begin{abstract}
The aim of this article is to show that focus groups (FGs) are a relevant method for the study of social representations of ecological practices and the meanings they have acquired in different socio-cultural contexts. First, relevant theoretical elements about ecological practices and representations are mentioned. Then, our different steps of designing FGs are detailed. A comparison between French and German FGs illustrates different processes of social representations and evidences how the tasks and stimuli structure group discussions about practices. Results highlight the role of the majority's opinion in facing scientific uncertainty and in the evaluation of ecological practices. They also point out different ways of anchoring them. For the French participants, ecological practices are means of acting according to political values, whereas for the German group members, they are compromises between individual and altruistic interests. Furthermore, the potentialities of FGs are discussed.
\end{abstract}

Keywords: ecological practices; focus groups; France; Germany; social representations

\section{Introduction}

From the beginning, when Merton (cf. Merton \& Kendall 1955) defined the notion of focus group (FG), they have been considered a specific methodology for the collection of qualitative data. Their particularity, as differs from later use in the marketing field, lies in the capacity of structuring discussions using a variety of tools and stimulations so as to channel debates toward specific research questions (Kitzinger, Markova \& Kalampalikis 2004). Another specificity of FGs is the possibility for the researcher to maintain the focus of the discussion and so make available interactions as research data (Kitzinger 1994; Morgan 1996, 1997). With an example, this article aims to evidence the relevance of the FG methodology in social psychology, namely in the investigation of social representations of ecological practices. Ordinary social knowledge is one of the matters of the social representations approach. Our article will discuss how FG research can give access to "more subtle aspects" of daily knowledge than the ones usually described in attitude studies (Waterton \& Wynne 1999, p. 129).

Ecological issues have become more and more important in our society, and people are asked to change their daily practices toward a more ecological behavior: recycling their waste, taking the bus instead of the car, eating local and seasonal products, and so

Correspondence: Dr. Sabine Caillaud, Laboratoire de Psychologie des Menaces Sociales et Environnementales, University Paris Descartes, Institute of Psychology, 71 Avenue Edouard Vaillant, Boulogne-Billancourt, 92774, France. E-mail: sabine.caillaud@ parisdescartes.fr 
forth. In this context, researchers and politicians are interested in understanding people's representations of such practices.

We conducted a broad survey in France and Germany about the social representations of ecological problems and practices within a qualitative research design based on methodological triangulation (Flick 2008). The design included FGs that examined the social representations of ecological practices.

This article is organized as follows. First, we detail the theoretical background of our study. Relevant quantitative results about ecological behavior and their limits are briefly reported. The social representations approach and FG research are presented as a possible way of coping with these limits. As a guide to our research, we outline some of the specificities of ecological practices in France and Germany. We explain how FG discussions were structured and analyzed. Second, we present our results and illustrate with examples how FGs can highlight key elements for understanding the way people represent ecological practices. Finally, we discuss our results highlighting FG potentialities for analysis of significant practices in different cultural contexts.

\section{Attitudes, Values, and Patterns Explaining Ecological Behavior}

Numerous studies refer to the Theory of Planned Behavior (Knussen et al. 2004; Lam \& Chen 2006) to understand the link between environmental attitudes and behaviors, or the Value-Belief-Norm Model (Groot \& Steg 2008; Oreg \& Katz-Gerro 2006). It is not our aim here to give an overview of this important research area (see Barr 2007 for a synthesis); however, some results are particularly relevant for our purpose. In fact, different "patterns" (or "attitudes") (Milfont, Duckitt \& Cameron 2006; Schultz 2000) can explain why people act, or intend to act, environmentally: biospheric (e.g., protect all living things like plants, animals), egoistic (e.g., protect my health, my future), and altruistic patterns (e.g., protect children, all people, people from my community). In a different way, Lindenberg and Steg (2007) suggest that three goals frame the way people act: hedonic, gain, and normative. They show that contradictions between goals and motives are possible in a given situation and that only the normative leads to ecological behavior.

Various theoretical approaches are used in these studies. However, they all rely on opinion polls and refer to the attitude approach. Their results are noteworthy, no doubt, but in some respects they are confronted with well-known methodological and theoretical limits (Billig 2004; Gaskell 2001; Howarth 2006; Wagner 1998; Waterton \& Wynne 1999), the most important restrictions being that the social and cultural dimensions are not taken into account and the focus placed on individual cognitions rather than social aspects. Attitudes are static and thus unable to explain changes. We propose a different theoretical and methodological approach to overcome these limits.

\section{Social Representations and Focus Groups}

\section{Social Representations and Practices}

"Representation is the production of meaning through language" and can be analyzed through discourse (Hall 1997). Indeed, through daily communication, among other processes, social representations are constructed and transformed into what Moscovici (2001) called the "thinking society."

The social representation (SR) approach offers specific advantages for studying people's relationship to the environment. For example, the environment can be considered as 
more than a place in which we live. It is also the object of social representations, an object related both to identity dynamics and to a given social and historical context (Jodelet 1998). This approach provides a framework with which one can make sense of certain paradoxes observed in lay knowledge (Castro \& Lima 2001). Since social representations are both constructed and shared on a local and global level they can take into account the double aspect of local and global ecological problems (Castro 2006).

This theoretical approach also invites us to study practices in a different way. Two distinctions are worth noticing. First, SRs are not interested in ecologically effective behaviors but in relevant practices that people themselves consider as ecological. So, SRs pay attention to action (which is different from behavior), because action results from the sense people attribute to their practices (Cranach et al. 1982; Jodelet 1991).

If the distinction between action and behavior has become obvious, this does not go for the relationship between social representations and practices. This leads us to our second point. According to Wagner (1994), many studies follow a research design which considers a causal link between social representations and practices. However, "originally social representations are not conceived as cognitions simply intervening between stimulus and behavioral response but rather as symbolic structures linking both stimulus and behavior" (Wagner 1994, p. 244). Meaning and representation are constructed through significant practices in a specific cultural and social context (Hall 1997). Consequently, when people act, they reconstruct their reality and represent it in the same way as when they talk, and this because their actions result from intentions (Moscovici 2001). Therefore, by studying the social representations of ecological practices, we are looking for significant practices which can only be understood in their specific cultural and social contexts granting them relevance and legitimacy.

\section{National Comparisons to Highlight Anchoring and Objectification Mechanisms}

Specific mechanisms were described in the first definition of the theory of social representation (Moscovici 2008). Social representations of a new object are woven into preexisting knowledge. The new object is anchored into an existing network of significations that are actually shared by the group and relevant for the object. Moreover, the abstract notion becomes concrete through the mechanism of objectification where images or metaphors are linked to the new object.

Our aim is to highlight these processes through group discussions. Hence, the social and cultural contexts become a variable in our research design. In fact, we chose to conduct a comparative study between France and Germany. Recent studies describe quantitative differences between French and German attitudes and environmental behaviors (Eurobarometer: Eurobaromètre 58.0 2002; Special Eurobarometer 2005). Sociological studies have also highlighted important differences, both in eco-counselors (Rudolf 1998) and in the heart of public discourse on certain environmental questions such as waste (Keller 1998). These very differences are sometimes explained by an ancient heritage, such as the philosophical current of the Age of Enlightenment in France and the Romantics in Germany (cf. Caillaud, Kalampalikis \& Flick 2012). We can therefore expect social representations to be quite different, not only as regards the construction and transformation processes but also with respect to their content.

Thus, our central questions are: How do people represent ecological practices? In which network of significations are ecological practices anchored? How are they objectified? 


\section{Using Group Interactions}

In the context of the social representations approach, FGs have been compared to a "thinking society in miniature" (Orfali \& Markova 2002) or a communication space allowing for initiation, observation, and analysis of interactions, recollections, and representations in the making (Kalampalikis 2004). In this sense, group dynamics and influencing processes, well known in social psychology at least since Lewin (1944), are no longer considered as biases in the analysis of opinions, but become useful to understand the way social representations are constructed and transformed (Lunt \& Livingstone 1996). Therefore, it can be more interesting to compare group discussions not only as regards the different opinions that emerged but also concerning the different processes the groups went through (Barbour 2008; Myers \& Macnaghten 1999). This does not mean that we should forget the content of the discussion, but it highlights the fact that processes are as important as contents when FGs are conducted and analyzed. This implies close attention to context and interactions in FGs if we want to exploit their potentials (Bloor et al. 2001; Kidd \& Parshall 2000; Kitzinger 1994).

Combining the social representation approach with FG methodology appears as a possible way to overcome the previously underlined limits: this combination comprises the social and dynamic construction of knowledge as well as the context of data production. However, our aim here is not to give exhaustive results about these SRs, but to present the potentials of FGs to gain better comprehension of ecological practices.

\section{Methodology: Structuring Focus Groups}

\section{Proposing Relevant Stimuli}

According to Kalampalikis $(2004,2011)$, we developed a group task inviting people to explain how they act to protect nature and why they perceived their action as being ecological. Once the group had discussed some images about nature and green-house gas production in different countries, we asked the participants to list their different ecological practices. So, participants themselves decided about relevant practices. Then we asked them to debate about the efficiency of the practices. One member of the group wrote the different practices on a board. Then the participants had to categorize them on a four-point scale as very efficient, efficient, only a little efficient, or not efficient at all and the practices were marked accordingly. When presenting the task to the group, we made it clear that the most interesting component was the debate, and not the consensus on how to categorize the discussed practice. The groups were thus invited to discuss each practice and to maintain disagreement. The specific instruction was:

What daily practices do you have which, according to you, contribute to protect nature? I suggest you list them and then try to choose together in what way each action is efficient or not and why? (Moderator demonstrates an example on the board.) You don't have to agree with one another each time, what matters more is the discussion. Who wants to write? ${ }^{1}$

\footnotetext{
${ }^{1}$ The instruction explicitly refers to practices "protecting nature" and not to "ecological" practices. This was a matter of translation: contrary to French, in German the adjective "ecological" is not commonly used and is therefore not well understood. However, according to our theoretical assumptions, the instruction leaves the definition of "efficiency" open to debate.
} 
Table 1

Documents proposed during focus groups

\begin{tabular}{|c|c|}
\hline What we want to observe & Document/task proposed \\
\hline Symbolic dimensions of nature protection & Images from earth \\
\hline $\begin{array}{l}\text { Semantic dimensions of ecology: local } \\
\text { and global dimensions of pollution }\end{array}$ & $\begin{array}{l}\text { World map with green house gas } \\
\text { production for different countries }\end{array}$ \\
\hline Representations of practices' efficiency & To list and evaluate their practices \\
\hline Representations of practices in daily life & $\begin{array}{l}\text { Comic strip: practices in context (local } \\
\text { practice/global effect; different motives, } \\
\text { compromise, etc.) }\end{array}$ \\
\hline
\end{tabular}

This task is intentionally rather similar to questions asked in surveys and attitude studies. The main difference is that participants are asked to reply after debate, thus their reasons and arguments are presented as more important than the answer itself. After this task, and as conclusion, a comic strip was shown to the group. It portrays a father filling up a small swimming pool with water. Simultaneously, he is explaining to his children that water is precious and that, when filling the pool, they are consuming as much water as an African family would in three months. Finally, he says that they will not put chlorine in it, so that they can reuse the water for the garden. He calls it an "ecological compromise." This document was retained because relevant themes are presented: the link between local practices and global problems, the tension between altruistic and egoistic motivations and so forth. Discussions around this comic strip also brought about relevant results, although groups often repeated previous explanations in more detail. Table 1 shows the different documents used for focus groups and what we meant to observe with them. Only the results about practices are presented here (gray squares).

These tasks were well accepted by the groups, and sometimes it was easier for them to discuss their daily practices than green-house gas production. Most of the time, the groups moderated themselves well, and the moderator only intervened when necessary to refocus the group's attention on the given task. The moderator also asked the group to explain elements which were "taken for granted" as well as go into details on the debates they tried to avoid (Barbour 2008).

\section{Sampling, Places, and Transcriptions}

In this study, purposeful sampling was applied. Its logic and power "lie in selecting information-rich cases for study in depth" (Patton 2002, p. 230). This is quite different from a random sampling with the aim of generalization. We included cases with a maximum variation, applying the logic that "any common patterns that emerge from great variation are of particular interest and value in capturing the core experiences and central, shared dimensions" of a phenomenon (p. 235). Age (Schuster 2003) and professional area of potential participants (De Haan \& Kuckartz 1996) were relevant factors for our sampling. In fact, people from the medical field, for example, are expected to be more aware of environment related health consequences. Others (e.g., jurists, social workers) are supposed to be more aware of social aspects and of material consequences (architects or engineers). Moreover, we included participants between 28 and 40 years. In fact, studies have shown that within this age range relations to nature (and to protecting nature) are heterogeneous and that 
the gap between attitudes and behaviors is the widest (Schuster 2003). The aim is not to test hypotheses related to these variables but rather to ensure enough diversity in opinions related to environment protection (Ritchie, Lewis \& Elan 2003). None of the participants was engaged in an ecological group as we wanted to exclude unusual cases. Only a few of them had children. For the Germans, we took into account where they had been raised (half in East Germany and half in West Germany), but no effect was observed in FGs. A description of the members of each group and codes used for quoting participants are presented in Tables 2 and 3. They show that groups in both countries are rather similar in their composition and can be compared.

Ten focus groups with four or five participants were conducted in France $(\mathrm{N}=4)$ and in Germany $(\mathrm{N}=6)$. Some of the members knew each other, whereas others did not know anyone. This was no problem for the discussion, because nature protection is a well-known and social topic often discussed in society. It appears as an issue people have heard about and know how to speak about. The debates took place in the home of one of the participants or, for some groups, in a room at university. It is obvious that the location had an effect on the discussion (Barbour 2008). For example, we noticed that the participants needed more time to begin telling jokes in the institutional context. But we will not analyze this here.

Table 2

Description of German FG participants

\begin{tabular}{|c|c|c|c|c|c|c|}
\hline Country & FG & Participants & Gender & Age & Profession & Has children \\
\hline \multirow[t]{25}{*}{ Germany } & \multirow[t]{4}{*}{ FG D1 } & $\mathrm{Sa}$ & $\mathrm{F}$ & 32 & nurse & 0 \\
\hline & & $\mathrm{J}$ & $\mathrm{F}$ & 28 & nurse & 2 \\
\hline & & M & $\mathrm{F}$ & 28 & nurse & 2 \\
\hline & & $\mathrm{Su}$ & $\mathrm{F}$ & 29 & nurse & 1 \\
\hline & \multirow[t]{4}{*}{ FG D2 } & $\mathrm{C}$ & $\mathrm{F}$ & 35 & jurist & 0 \\
\hline & & $\mathrm{L}$ & M & 28 & psychologist & 0 \\
\hline & & B & M & 29 & manager & 0 \\
\hline & & S & M & 28 & jurist & 0 \\
\hline & \multirow[t]{5}{*}{ FG D3 } & M & $\mathrm{F}$ & 30 & doctor & 0 \\
\hline & & Iv & M & 29 & marketing & 0 \\
\hline & & $\mathrm{R}$ & M & 31 & engineer & 0 \\
\hline & & $\mathrm{D}$ & M & 35 & dietician & 0 \\
\hline & & $\mathrm{B}$ & $\mathrm{F}$ & 37 & doctor & 0 \\
\hline & \multirow[t]{4}{*}{ FG D4 } & $\mathrm{D}$ & $\mathrm{F}$ & 34 & nurse & 2 \\
\hline & & $\mathrm{C}$ & M & 34 & nurse & 0 \\
\hline & & $\mathrm{S}$ & $\mathrm{F}$ & 29 & nurse & 0 \\
\hline & & $\mathrm{L}$ & $\mathrm{F}$ & 35 & nurse & 0 \\
\hline & \multirow[t]{4}{*}{ FG D5 } & Ach & M & 41 & marketing & 0 \\
\hline & & An & $\mathrm{F}$ & 31 & engineer & 0 \\
\hline & & M & M & 35 & architect & 0 \\
\hline & & $\mathrm{F}$ & M & 35 & engineer & 1 \\
\hline & \multirow[t]{4}{*}{ FG D6 } & $\mathrm{J}$ & M & 29 & unemployed & 1 \\
\hline & & $\mathrm{E}$ & $\mathrm{F}$ & 28 & artist & 0 \\
\hline & & $\mathrm{S}$ & $\mathrm{F}$ & 29 & nurse & 0 \\
\hline & & $\mathrm{R}$ & $\mathrm{F}$ & 29 & international relationships & 0 \\
\hline
\end{tabular}


Table 3

Description of French FG participants

\begin{tabular}{ccccclc}
\hline Country & FG & Participants & Gender & Age & Profession & Has children \\
\hline France & FG F1 & J & M & 39 & doctor & 3 \\
& & S & F & 39 & jurist & 3 \\
& & Ch & M & 40 & physiotherapist & 0 \\
& \multirow{6}{*}{ FG F2 } & Ca & F & 40 & psychologist & 0 \\
& Cé & F & 32 & artist & 2 \\
& E & F & 32 & artist & 1 \\
& & Ro & M & 31 & grocer & 0 \\
& FG F3 & Ch & F & 38 & unemployed & 0 \\
& Se & F & 30 & social worker & 0 \\
& J & F & 33 & engineer & 0 \\
& G & M & 28 & social worker & 0 \\
& FG F4 & So & F & 34 & grocer & 0 \\
& L & M & 28 & architect & 0 \\
& O & F & 28 & architect & 0 \\
& & S & M & 31 & architect & 0 \\
& & A & F & 28 & architect & 0 \\
\hline
\end{tabular}

The FGs were audio recorded and transcribed. Video recording was not relevant in our research because we did not plan to analyze nonverbal communication. Moreover, the transcriptions followed simple rules which correspond to the planned analysis. Thus, commas refer to short pauses (one second), suspension points refer to pauses between one and three seconds, and in brackets we wrote out observations of particular events such as laughing, long silences, and so forth.

\section{Structuring FG Analysis}

The method we used in this article is based on the principle of thematic encoding developed by Flick $(1996,2007)$ for the analysis of interviews in comparative studies which is, in turn, inspired by the measures proposed by Strauss (1987). The starting point of this technique was the idea of distribution of knowledge according to social groups. In other words, it is particularly relevant in the research on SR because SRs are shared by the members of one and the same group (Flick 1996). Generally, the primary case analysis is followed by a cross-examination based on the differences and similarities of each case. The specificity of our study lies in the application of the Flick method $(1996,2007)$ to the analysis of FG and thereby in considering group interaction.

The first step of the analysis consisted in case to case (here: group to group) open coding (Straus 1987) of the data. This means, first of all, "intensive reading" with the following questions: "Who says what to whom? What is happening? What is taken for granted?" By "intensive reading," we mean that particular attention is paid to different elements of the way people talk to find out the codes and interpret the data: pronouns, perspective taking, lexical choice, rhetoric, and narratives. The variable properties of discourse are influenced by mental models, by the participants' representations of a "context" (Van Dijk 2008). We did not conduct discourse analysis, but we used these discourse properties as indicators 
of the participants' representations. This makes quite a difference. Therefore, these aspects of discourse supported the interpretation of data and the elaboration of codes.

The next step was the transfer of these codes to a table reproducing the series of the themes that were discussed. Thus, the order of appearance was preserved and the preceding or following issue could be consulted at any moment. The initials of the participants who suggest a topic, who debate on a topic or who simply showed agreement or disagreement also appear on the table. The initials were marked by signs (e.g., equal sign, lightning sign) in order to report disagreement, conflict, or consensus. Using this type of table allows for taking into account speaking turns, evidencing interactions (minority wining over majority, normalization, consensus, etc.), and, above all, for establishing the link between group dynamics and the issues addressed (Table 4 shows an extract from the table). Each FG has its own table. Once this preliminary work for each FG was done we grouped the codes used by the FG into general categories. Finally, a kind of a summary, close to what Strauss (1987) calls "memo," of each discussion was written which recalls the main topics and key moments of the group dynamics.

Once this first set of steps behind us, we gathered the codes used by all FG in more general categories. This enabled us to check whether a topic was present versus absent. Table 5 shows overlapping of the general categories in the two countries even though they also sometimes refer to more specific different contents, in which case the dynamics of the discussion no longer appears. Nevertheless, the index of topics yields an interesting basis for the ongoing analysis since it enables to initiate the comparison between the various FG. The general categories then lead us back to the initial encoding. So the categories were questioned systematically: Why is a topic present in the FG of both countries? Why is it absent in one of the countries, or in one FG? In which kind of situation does a topic rise? Which is its link with a particular group dynamics? To answer these questions we based ourselves on Strauss' (1987) axial encoding procedure.

Therefore, thematic and dynamic analyses were combined into a dialogical unit to highlight patterns the groups followed. These patterns emerged through what Patton (2002) calls the "logical analysis." The different dimensions were cross-classified to generate new insights about how the data can be organized (i.e., how themes are linked together and are linked to specific interactions). For example, we looked for regularities in the way practices were evaluated and it appears that in each case the majority impose its opinion. Asking why?, we turn back to our data and found that it happens when groups have the feeling that

Table 4

Open-coding process

\begin{tabular}{ll}
\hline Participants & \multicolumn{1}{c}{ Open-coding } \\
\hline $\mathrm{Ch}$ & $\begin{array}{c}\text { Proud vs. happy that, compared to } 10 \text { years ago, we pollute less/it still } \\
\text { remains a problem with the cars } \\
\text { Discussion about the instruction }\end{array}$ \\
$\mathrm{All}$ & «we », sorting of the waste, asking for agreement \\
$\mathrm{J}=\mathrm{Ch}$ & Afraid not to fill in the sheet \\
$\mathrm{S}=\mathrm{Ch}$ & It depends on the others; referent «we » \\
$\mathrm{S}=\mathrm{Ch}$ & "we » switch off the appliances in sleep mode \\
$\mathrm{J}$ & Who is responsible for these practices at home? \\
$\mathrm{S} \neq \mathrm{J}$ & Shorten the debate by saying it is only a little efficient \\
$\mathrm{Ch}$ &
\end{tabular}




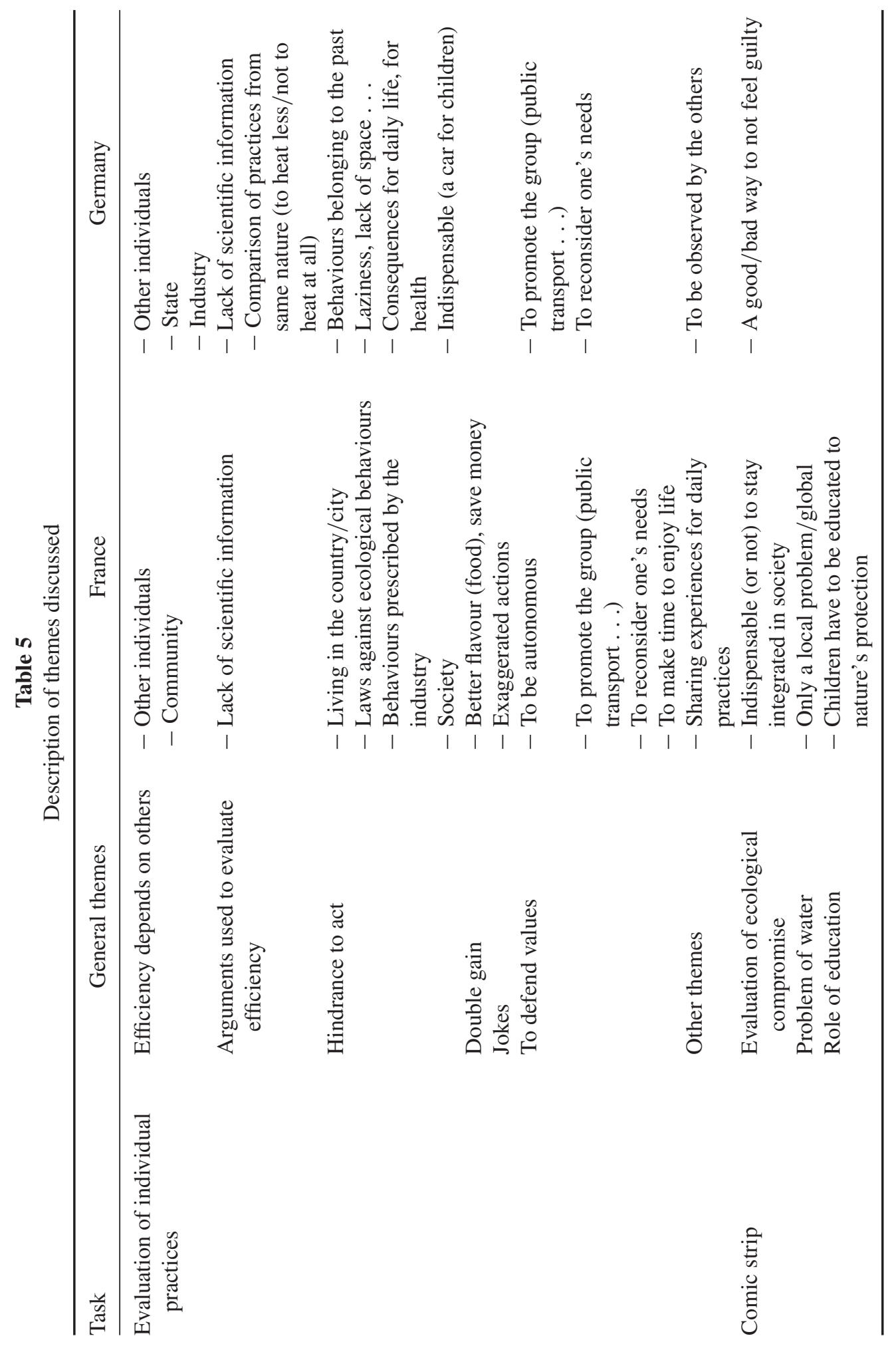


the task is irrelevant. Asking why?, they have this feeling we look for the codes preceding and so forth. Patterns emerged during an inductive analyze; however, once this patterns have been established we test the appropriateness of our analysis by examining deviate cases (Patton 2002). Cases which did not fit well were used to complete/modify the pattern. The presentation of these results describes this patterns and gives examples which underlie our analysis and interpretation.

\section{Results}

Table 4 provides an index of the themes. Differences and similarities are observed in German and French groups. However the general themes are quite similar to attitude studies. We will present the patterns that emerged, i.e., the dynamics of the discussions and the way themes are linked, to show the relevance of FGs.

\section{Role of the Majority in Evaluating Practices}

When we planned the FGs, we expected that participants would debate about the efficiency of their practices at a "scientific level." We expected participants to choose causal relations to evaluate their practices, such as buying organic products produced without pesticides to ensure a minimal harmful effect on nature. Besides, we expected participants to use other forms of knowledge, for example, political or economic. But it is worth pointing out that scientific reasons seemed insufficient for their discussions. In fact:

FG D3 R: Indeed to buy local products, in the same way ok we have to think about for example local products if we take an apple we want to buy in spring, the local apple has to be preserved in some way, some gases are used and some cold storage rooms too and so on, and then this apple is as harmful as the apple that comes from New Zealand by boat

M: It has been treated in the same way

$\mathrm{R}$ : Yes it's ok but it has not stayed as long in a cold room but it had the same gas treatment for sure

M: We can also eat just seasonal apples

B: We can do that for example

In this extract, $\mathrm{R}$ and $\mathrm{M}$ are talking about apples. Scientific arguments are based on probable facts, but neither $\mathrm{R}$ nor $\mathrm{M}$ have any idea about what really happens with an apple. As final consequence, they choose to eat only seasonal apples. Thus, in many situations the participants have doubts, which turn satisfactory answers unrealistic. For example, in the same group, one participant asked if it was really better to take the streetcar rather than the car, "even if the streetcar is empty." This question influenced the group to favor other alternatives such as biking or walking.

This uncertainty engaged the groups in other strategies to accomplish the task and give meaning to the scale proposed for efficiency evaluation of their practices. Different coping strategies were observed. Sometimes, the groups compared individual practices to industrial or political ones (FG F1, F2, F3 and FG D1, D3, D6). Some groups proposed different levels of efficiency for a same set of practices (FG D1, D3, and D5). In the following example, we observe one German group debating about the efficiency of heating: 
FG D3 D: All this is efficient, I will say now efficient, I mean very efficient would be not to heat at all, that's the most efficient

In some groups, however, the efficiency scale was explicitly described as not relevant and this questions the relevance of the material chosen for the discussion. They considered that whatever the practice, it can be useful provided everyone follows, or useless if no one acts the same way. For one German group, here is what participants said when debating about saving electricity:

FG D5 Ach: So I think it is very efficient, efficient would be a question of definition for me, it's inefficient because it has no effect, what I do in my little environment. Or I would say that, everybody must do one thing and then it will be a very good thing I mean, but between very efficient and inefficient there is nothing in my opinion

F: That we individually

Ach: It's my opinion

F: That we only change a little it's obvious, but we must if everybody says that

Ach: Yes everybody

F: Nevertheless it would be

Ach: How many points for the scale?

M: Four points

F: I would put it on three, it is a little efficient but

An: I will too

M: Should we keep a democratic voice (hubbub) is there a middle ground?

Ach: No put it as you want it's a democratic three to one

In this example, the group is confronted with a paradox of ecological practices: individual practices are only efficient if many people act in the same way. What happens if the group considers this fact? As this excerpt shows, the group advantaged the majority's voice (a "democratic" one). We observed that in all the groups we conducted, the majority's voice became relevant when they had to face scientific uncertainty and the irrelevance of the question. Consequently, they strived for consensus. Later, in the same group:

FG D5 M: Donation to environmental organizations? . . Is it efficient, do you do it?

An: We do it

M: We do it yes

F: Of course it's efficient or very efficient

Ach: Did I ever do it?

M: Yeah we are already three you can do what you want it's efficient

In another group (FG D6), the participants debated about ecological cleaning products. One of the participants disagreed on their efficiency. The participant who was writing put two crosses on the board: a big one for very efficient (representing the majority's voice) and a small one for not efficient at all (representing the minority's voice).

These elements highlight the importance of the majority, and also of the group's approval, even if the group consists only of participants who did not know each other before. In fact, one French woman (so, in FG F3), working in an organic grocery store, heard from the others that organic products were not always better for the environment. 
Indeed, they explained to her how farmers use methods that are dangerous for the soil. Here is her reaction:

FG F3 So: But do they [organic producers] all work this way?

G: No they don't

So: But I will talk about it tomorrow at work, I will say that (she is laughing) I will never again eat organic, I will say to my customers to stop eating organic it's inefficient.

In another group (FG D4), one woman (S) was confronted to the fact that nobody else in the group recycled their waste. They all agreed that different types of waste were mixed up again so that their recycling became irrelevant. She felt very disappointed and wanted to call the recycling center to inquire.

The results are evidence that, in contexts where logical and scientific arguments are not sufficient, groups retain the majority's voice to evaluate the efficiency of their practices. If the majority deems the practices inefficient, the minority tends to feel disappointed and then evokes a possible change of actions. Of course, our method does not enable us to know if changes actually occurred. But, here the mechanism of decision making is relevant. In fact, these results reveal the importance of other people's representations and of shared representations in the context of ecological practices.

The role accorded to the majority is common to all group discussions. However, differences exist in the way French and German groups discussed hindrance to act and values defended (see Table 4). This discloses different anchoring mechanisms.

\section{A Pragmatic Evaluation for Moral Anchoring in German Groups}

In German FGs, during the discussion, the groups changed the question about efficiency into another topic. Nevertheless, the groups did not have the feeling they were answering a different question. Here is an example from a German group of nurses about using cars:

FG D1 Sa: Because when I go shopping I can't carry it all easy, theoretically we don't need a car, first there is public transport, and then there is the question do we need it or do we not, or is it actually, I know that for me, in the end, it's only more comfortable

M: I wouldn't have a car if I didn't have children

Su: That's what I wanted to say

M: Only because of the children so I will say how much money, first the money and then also for the environment, and then we notice that it is totally stupid so really we only need a car for the children, to quickly go to the pediatrician or to school, rather than the ways between the station and the school could be more rapidly done, if we would wake up half an hour earlier (she is laughing)

Su: That's real but when it is raining like today

M: Yes with such weather

In this excerpt, participants (all young women, most of them with children) are talking about the point in having a car: when they go shopping, when they bring children to school, and so forth. As underlined in this extract, the usefulness of the car may be debated: waking up earlier for example makes the car useless. By laughing, the participant $\mathrm{M}$ indicates that 
she is aware that her argument is debatable. Thus the initial question about the efficiency of their practices is changed into the issue of car usefulness. This was observed in all German groups for a large majority of practices.

In some cases, the limits between the acceptable and the unacceptable are not the same for all participants. In one group, one member brought up the topic of eating less meat and fewer milk products, and a debate quickly rose:

FG D2 B: I'm a vegan level five I don't eat anything that has a shadow

L: Ok but it's a gradual thing you can

C: But it's better for the body to receive calcium in some way that's obvious . . . I don't know how you want to do that practically that you live without any animal products

S: Not be vegetarian but living on a vegetarian way

C: How do you eat healthy if you don't take medicine that will end up in the waste water?

B: You will die earlier if you live as a vegetarian (they are all laughing)

Here, it appears that jokes become a way for groups to find a consensus when it is impossible to draw a limit between the acceptable and the unacceptable.

At this stage, one question emerged: why did the German groups anchor the debate in the acceptability of practices? Why did they agree on some restrictions?

We examined some paradoxes to answer the question; one of them is related to recycling waste. If all groups agree that household waste is mixed up again, they all recycle a little (e.g., paper and/or glass and/or plastic bottles). Moreover, in one group of nurses (FG D4), only one woman (S) recycles (previously mentioned). Another participant (D) says to her: "you do it for nothing. I find that really good." Another group (FG D5) notices that they all think that it is inefficient but that they still all do it.

We can give meaning to these paradoxes by considering the words used. In fact, FG D3 chose particular notions to write practices on the sheet such as "heating consciously" and "consuming meat consciously." Can we conclude that these restrictive practices have a moral signification? Other details in other groups confirm this hypothesis. For example, when talking about the three colors of glass they put into one recycling container with three separate compartments, FG D5 said:

FG D5 Ach: I really looked at it and I thought it's impossible they're taking the piss out of me aren't they, they came with the truck, lifted the container opened it, hop and it all fell I said what

F: All in the same or what?

M: Yes it was obvious

Ach: Yes of course they opened it and it all fell in

F: Are there not three compartments in the truck

Ach: No they just opened it and it all fell in

What does this narrative reveal? It is not the inefficiency of their practices that seems to shock people about all the recycled goods being mixed up again, but the lie they discover: "they take the piss out of me." $\mathrm{F}$ tries to find a possible explanation. Dishonesty is not accepted. So, this narrative highlights a moral dimension.

In the same way, talking about the comic strip, a small affirmation from one participant, based on obviousness, was approved by all the other members and outlined a consensus: 
FG D4 S: So I think we actually do a lot

D: A donation for Christmas

C: Obviously

D: So he has a good conscience

We observe an identification process with the father (by using the different pronouns "we" or "he"). The group highlights the moral aspects of these practices by comparing ecological compromises such as donations for Christmas. The topic "to be observed by the others" (see Table 4) also refers to a moral anchoring.

In the different elements cited (and others we could not show here), restrictions linked to ecological practices take moral meaning. It appears that social representations of ecological practices in Germany are anchored in a tension between personal and altruistic interests.

\section{Practices Representing General Values in France}

Results presented for Germany become even more noteworthy by presenting the different contents and interactions in French Groups. Here is a French example:

FG F3 J: I compost

Se: Oh she lives in the countryside

J: Yes that's why I can do that

Se: I am careful to save water ...

$\mathrm{J}$ : To salvage rain water

Se: I can't I don't even have a balcony (laughing)

As this excerpt shows, Se outlines different material limitations to act environmentally: she cannot compost or salvage water because she does not live in the countryside. These are concrete examples of the way the French debate about practices (see Table 4). But this tension between what people want to do on one hand and what is possible for them to do on the other mentioned on different levels. It ranges from a practical to a political vision of society.

FG F2 Cé: So it's what we also said about guilt when you use how do you live then, and how do you do to say ok if I have to fly for my job because I must go to Finland for example, yeah I go ok I know that I'm doing something wrong but we must live too we can't cut ourselves off from the rest of the world I don't really want to go back 150 years earlier so that I stay at home and take care of the children

$\mathrm{Ch}$ : So we come back to a society that must change as you said going to work in Finland ok you have no choice if you can't fly, so it would have to be a society where it is not necessary that you go to Finland and come back three days later

Cé: Oh yes, it must be possible to take two weeks to go there

With this example (working in Finland for three days), the group conjured up a new society where it would not be necessary to travel for short periods of time. In France, groups discussed practices in a tension between what they want to do and what society and material possibilities enable to do. In the compost example, Se explains that she wanted her block of flats to organize collective compost. In comparison with the German discussions here, the impossibility of ecological practices cannot be accounted for by individual comfort but by 
the way of life in which the practices are embedded. Practices are therefore not perceived as restrictions for the individual, which makes a huge difference. The danger however is to be excluded from society, or to feel "guilty."

We can observe that a specific group dynamic is linked to this theme. The French participants (in the four groups) proposed general actions and then they all gave specific examples; like, architects shared their experiences about saving water:

FG F4 S: Then saving water I suppose that we all do that . . not to run water

A: Yes

O: I bought some little nozzles which reduce to a half the flow

A: Yes

S: Oh the flow?

O: In the shower it puts in air so you have the feeling that you have pressure when you wash your hands and so on you know, but it's possible that it takes more time if you have

L: To fill a glass

S: I, I put a toilet flush

O: You know that too?

A: Yes

S: I put a flush with two-speed in my toilet, a little flush a big flush

A: Oh the knob from the shower I have you can stop it when you soap yourself

Here the analysis tends to show that they are proud of their actions: brief turn taking, repeated use of the pronoun I. Participant $\mathrm{O}$ seems surprised and disappointed (in her voice) that A knows about her idea, and S also wants to retain the group's attention with his action. Here, every small daily practice is a way to show the others that one is doing something. So these practices may appear as a way of acting according to one's own free will. Ecological practices are therefore evaluated on their symbolic dimension. In fact, in one group, the members considered the scale as follows:

FG F2 R: We can put very efficient everywhere if it is well done it's all efficient

Cé: It means that we have to reflect about each action we do, it's standing back and not swallowing everything they want us to believe

$\mathrm{R}$ : So maybe if we want to keep this board we could choose if we have to change one thing in our life what would it be first so that it would be very efficient and that would have a very big gain . . . a big gain for environmental protection . . . and as we have concepts that are

E: I would choose sobriety

Ch: It summarizes all and all result from

The participants in this group choose to retain the notion of sobriety, because it somehow comprises all the practices they have listed, although it is one of them. This notion transforms all practices into a way of life to be adopted. All the French groups tend to summarize their list or retain the most efficient practice. This dynamic is specific to French groups. It evidences that practices take meaning in a broader way and are understood as symbols for more general values. Individuals then tend to find a solution to the paradox between their values and the way of life society imposes on them. Therefore, daily practices also represent one's willingness to be accepted by society and not to be cut off: 


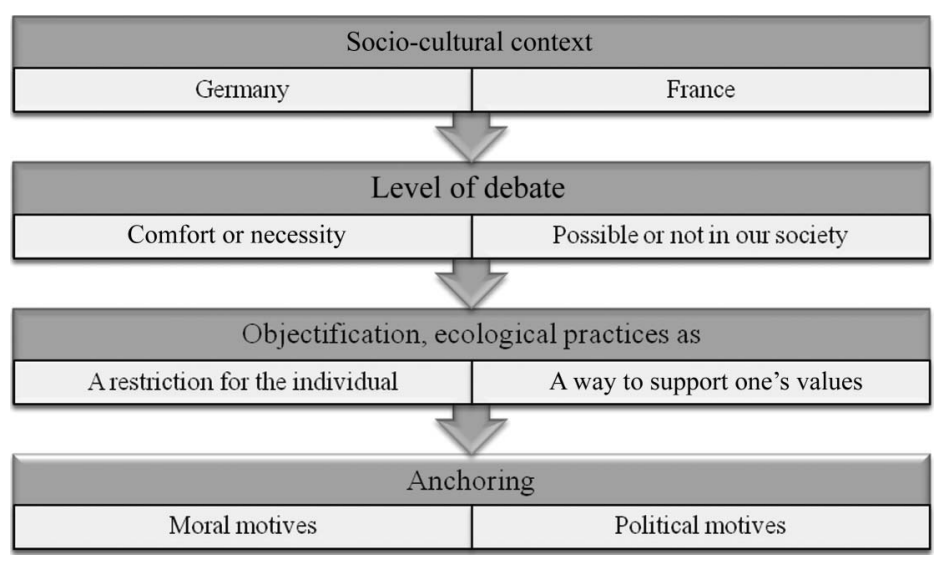

Figure 1. Summary—contents and processes in France and Germany.

FG F3 G: To give an example I have a friend she is really I call that uptight, it makes me nervous who is eating organic who will never give any sweets to her children, my little darling that's all junk yes but I love them mum this junk (they are laughing) so yes give these strawberry sweets to your daughter, we are nevertheless very rational at other moments but that it makes me think about

Summarizing the results for the French corpus (see Figure 1), we outline that social representations of ecological practices are anchored in a tension between individual values and a social way of life. This gives ecological practices political dimensions due to their symbolic way of acting against our consumerist way of life.

\section{Discussion}

We would like to summarize the different results obtained through our analysis before proposing some thoughts about focus groups. First, our data highlight the roles played by the majority when groups have to evaluate the efficiency of their ecological practices. The tendency to favor agreement, despite specific instructions, explains why groups have recourse to humor and jokes. Favoring agreement allows for consensus, even though feeble, because the limits between the acceptable and the unacceptable remain undetermined in the German groups. In the French groups, consensus is reached by accepting the diversity of concrete practices referring to the same symbolic act.

Results also showed that logical explanations and scientific arguments were not enough to evaluate practices; this supports the hypothesis of "cognitive polyphasia" understood by the social representations theory as a polymorphic state of consciousness (e.g., language, thinking, and knowledge) that social subjects utilize in their interactions in a systematic or heuristic fashion (Kalampalikis \& Haas 2008; Provencher 2011). Therefore, the group's opinion becomes a means of evaluating practices with the heuristic idea that "if all people do something, it has a positive effect."

Subsequently, we defined different anchoring modes in France and Germany. In Germany, social representations of ecological practices are anchored in a tension between personal and altruistic interests. Practices are compared to restrictions and donations. They become a form of redemption and are thus objectified. In France the limits 
of ecological practices are not perceived in terms of self-interest but rather in relation to society. In fact, according to the French participants society constitutes an obstacle for individuals to act according to their personal values. Therefore, social representations of ecological practices are anchored in a tension between acting in accordance with one's own values and staying integrated in society. Thus, ecological practices appear as political actions. This main result echoes the historical analysis of green movements in both countries: in Germany local movements were unified on grounds of ethical values, whereas in France two movements emerged: a scientific one and a political one (Chibret 1991). It is also in accordance with a sociological study that emphasizes the idea that ecological practices in France can be considered as "ordinary resistance" (Dobré 2002).

\section{Conclusion}

In this article, we outlined several issues addressed by FG research. First of all, we explained the research design and we showed how each step contributed to improve the quality and the relevance of data. The sampling ensured enough diversity in responses. Moreover, the French/German comparison enhanced the cultural aspects of ecological issues and allowed for an explanation of the patterns which emerged. Additionally, the task proposed to the participants evidenced the practices they thought relevant and therefore contributed to the study of representations and significant practices. Finally, the comparison between a simple thematic analysis (see index table 4) and the patterns integrating interactions and content confirms the idea that FGs gain to be analyzed by taking into account group interactions (Kalampalikis 2011; Kitzinger 1994). Also, this article seeks to support that FGs are more than a simple method of data collection; they can be used as a research method which enables theoretical interpretations and result production. In considering both content and group dynamics, FGs highlight processes that are ignored by survey data like attitude studies.

The second point we would like to develop in this conclusion is related to the results themselves. We proposed a task commonly used in attitude studies: a scale to evaluate practice efficiency. However, our results show that the participants were not able to answer (or not interested in) the question; it was not relevant for them. This should not lead to the conclusion that scales in general are irrelevant; but in some aspects this state of facts questions the use of scales elaborated by scientists to measure scientific concepts which aim to explain the way layers act and think. Somehow, it also questions our material and the task proposed to the FGs: is it really relevant? Maybe not, but the method enables participants to transform and adapt the initial question. Therefore, the task becomes relevant to them, and enables the researcher to interpret the results. This is an important process that makes FGs a powerful method.

Our results give evidence for cognitive polyphasia underpinning group decisions relative to ecological practices: scientific knowledge is not enough for debate. The analysis of group interactions reveals the importance of the majority to decide if practices are efficient, even if the behavior itself has no direct effect on nature. Hence, due to its interactive and dialogical nature FG is a particularly adequate methodology for evidencing culturally and socially significant fields of tension where debates about meaning of ecological practices are anchored. These fields of tension do not only contain rational knowledge based on scientific reasoning, verifiable and truthful. They convey everyday social knowledge, common sense, with its plural, polymorphous and polysemous logic of action. The language of social representations carries in it this cognitive polyphasia (Kalampalikis \& Haas 2008). 
Practices are no longer analyzed as the results of individual attitudes; they contribute to the social construction of meaning in a dialogical way and are social significant practices. FGs give evidence that these practices are embedded in a broader vision of the world. Finally, the differences between both countries do not imply that one way of representing ecological practices is better than the other. They clearly show that ecological practices are diverse, significant and depend on the socio-cultural context. This ought to be taken into account in environmental studies in the light of social representations.

\section{References}

Barbour, R 2008, Doing focus groups, Sage, London.

Barr, S 2007, 'Factors influencing environmental attitudes and behaviors. A UK study of household waste management', Environment and Behavior, vol. 39, no. 4, pp. 435-73.

Billig, M 2004, 'Studying the thinking society: social representations, rhetoric, and attitudes', in G Breakwell \& D Canter (eds.), Empirical approaches to social representations, Oxford University Press, New York, pp. 39-62.

Bloor, M, Frankland, J, Thomas, M \& Robson, K 2001, Focus groups in social research, Sage, London.

Caillaud, S, Kalampalikis, N \& Flick, U 2012, 'The social representations of the Bali climate conference in French and German media', Journal of Community and Applied Social Psychology, vol. 22, no. 4, pp. 363-78. DOI: 10.1002/casp.1117

Castro, P 2006, 'Applying social psychology to the study of environmental concern and environmental worldviews: contributions from the social representations approach', Journal of Community and Applied Social Psychology, vol. 16, pp. 247-66.

Castro, P \& Lima, ML 2001, 'Old and new ideas about the environment and science. An exploratory study', Environment and Behavior, vol. 33, no. 3, pp. 400-23.

Chibret, R-P 1991, Les associations écologiques en France et en Allemagne. Une analyse culturelle de la mobilisation collective. Thèse de doctorat, Paris I, Paris, France.

Cranach, M, Kalbermatten, U, Indermühle, K \& Gugler, B 1982, Goal-directed action, Academic Press, London.

De Haan, G \& Kuckartz, U 1996, Umweltbewusstsein. Denken und Handeln in Umweltkrisen, Westdeutscher Verlag, Göttingen.

Dobré, M 2002, L'écologie au quotidien. Eléments pour une théorie sociologique de la résistance ordinaire, L'Harmattan, Paris.

Eurobaromètre 58.0, Les attitudes des Européens à l'égard de l'environnement 2002, European Opinion Research Group, Brussels, Belgium, viewed 11 April 2013, <http://ec.europa.eu/public_ opinion/archives/ebs/ebs_180_fr.pdf >.

Flick, U 1996, Psychologie des technisierten Alltags. Soziale konstruktion und repräsentation technischen Wandels, Westdeutscher Verlag, Opladen.

Flick, U 2007, Qualitative sozialforschung. Eine einführung, Rowohlt Verlag, Hamburg.

Flick, U 2008, Designing qualitative research, Sage, London.

Gaskell, G 2001, 'Attitudes, social representations, and beyond', in K Deaux \& G Philogène (eds.), Representations of the social, Blackwell Publishers, London, pp. 228-41.

Groot, J \& Steg, L 2008, 'Value orientation to explain beliefs related to environmental significant behavior: how to measure egoistic, altruistic and Biospheric Value Orientations', Environment and Behavior, vol. 40, no. 3, pp. 330-54.

Hall, S 1997, 'The work of representation', in S Hall (ed.), Representations. Cultural representations and signifying practices, Sage, London, pp. 13-74.

Howarth, C 2006, 'How social representations of attitudes have informed attitude theories: the consensual and the reified', Theory and Psychology, vol. 16, no. 5, pp. 691-714.

Jodelet, D 1991, Madness and social representations: living with the mad in one French community, University of California Press, Berkeley. 
Jodelet, D 1998, Les représentations sociales et l'étude du rapport homme/environnement', in AVD Rigas (ed.), Social representation and contemporary social problems, Ellinika Grammata, Athens, pp. 37-51.

Kalampalikis, N 2004, 'Les focus groups, lieux d'ancrages', Bulletin de Psychologie, vol. 57, no. 3 , pp. 281-9.

Kalampalikis, N 2011, 'Um instrumento de diagnóstico das representações sociais: o grupo focal', Revista Diálogo Educacional, vol. 11, no. 33, pp. 435-67.

Kalampalikis, N \& Haas, V 2008, 'More than a theory: a new map of social thought', Journal for the Theory of Social Behaviour, vol. 38, no. 4, pp. 449-59.

Keller, R 1998, Müll - die gesellschaftliche konstruktion des Wertvollen. Die öffentliche diskussion über Abfall in Deutschland und in Frankreich, Westdeutscher Verlag, Opladen.

Kidd, P \& Parshall, M 2000, 'Getting the focus and the group: enhancing analytical rigor in focus groups research', Qualitative Health Research, vol. 10, no. 3, pp. 293-308.

Kitzinger, J 1994, 'The methodology of focus groups: the importance of interaction between research participants', Sociology of Health and Illness, vol. 16, no. 1, pp. 103-21.

Kitzinger, J, Markova, I \& Kalampalikis, N 2004, 'Qu'est-ce que les focus groups?', Bulletin de Psychologie, vol. 57, no. 3, pp. 237-43.

Knussen, C, Yule, F, Mac Kenzie, J \& Wells, M 2004, 'An analysis of intentions to recycle household waste: the roles of past behavior, perceived habit, and perceived lack of facilities', Journal of Environmental Psychology, vol. 24, no. 2, pp. 237-46.

Lam, S-P \& Chen, JK 2006, 'What makes customers bring their bags or buy bags from the shop? A survey of customers at a Taïwan hypermarket', Environment and Behavior, vol. 38, no. 3, pp. 318-32.

Lewin, K 1944, 'Dynamics of group action', Educational Leadership, vol. I, pp. 195-200.

Lindenberg, S \& Steg, L 2007, 'Normative, gain and hedonic goal frames guiding environmental behavior', Journal of Social Issues, vol. 63, no. 1, pp. 117-37.

Lunt, P \& Livingstone, S 1996, 'Rethinking the focus groups in media and communications research', Journal of Communication, vol. 46, no. 2, pp. 79-93.

Merton, R \& Kendall, P 1955, 'The focused interview', in P Lazarsfeld \& M Rosenberg (eds.), The language of social research: a reader in the methodology of social research, The Free Press, Glencoe, IL, pp. 476-91.

Milfont, T, Duckitt, J \& Cameron, L 2006, 'A cross-cultural study of environmental motive concerns and their implications for pro-environmental behavior', Environment and Behavior, vol. 38, no. 6, pp. 745-67.

Morgan, D 1996, 'Focus group', Annual Review of Sociology, vol. 22, pp. 129-52.

Morgan, D 1997, Focus group as qualitative research, Sage, London.

Moscovici, S 2001, 'Why a theory of social representations?', in K Deaux \& G Philogène (eds.), Representation of the social, Blackwell Publishers, Oxford, pp. 8-36.

Moscovici, S 2008, Psychoanalysis. Its image and its public, 2nd edn, Polity Press, London.

Myers, G \& Macnaghten, P 1999, 'Can focus groups be analysed as talk?', in R Barbour \& J Kitzinger (eds.), Developing focus groups research. Politics, theory and practice, Sage, London, pp. 173-85.

Oreg, S \& Katz-Gerro, T 2006, 'Predicting pro-environmental behavior cross-nationally values, the theory of planned behavior, and value-belief-norm theory', Environment and Behavior, vol. 38, no. 4, pp. 462-83.

Orfali, B \& Markova, I 2002, 'Analogies in focus groups: from the victim to the murderer and from the murderer to the victim', European Review of Applied Psychology, vol. 52, no. 3-4, pp. $263-71$.

Patton, M 2002, Qualitative research and evaluation methods, Sage, London.

Provencher, C 2011, 'Towards a better understanding of cognitive polyphasia', Journal for the Theory of Social Behaviour, vol. 41, no. 4, pp. 377-95.

Ritchie, J, Lewis, J \& Elan, G 2003, 'Designing and selecting samples', in J Ritchie \& J Lewis (eds.), Qualitative research practice. A guide for social science students and researchers, Sage, London, pp. $77-108$. 
Rudolf, F 1998, L'environnement une construction sociale. Pratiques et discours sur l'environnement en France et en Allemagne, Presses Universitaires de Strasbourg, Strasbourg.

Schultz, W 2000, 'Empathizing with nature: the effects of perspective taking on concern for environmental issues', Journal of Social Issues, vol. 56, no. 3, pp. 391-406.

Schuster, K 2003, Lebenstil und Akzeptanz von Naturschutz, Asanger Verlag, Heidelberg und Kröning.

Special Eurobarometer, The attitudes of European citizens towards environment 2005, European Commision, Brussels, Belgium, viewed 11 April 2013, <http://ec.europa.eu/public_opinion/ archives/ebs/ebs_217_sum_en.pdf>.

Strauss, AL 1987, Qualitative analysis for social scientists, Cambridge University Press, Cambridge. Van Dijk, T 2008, Discourse and context. A sociocognitive approach, Cambridge University Press, Cambridge.

Wagner, W 1994, 'The fallacy of misplaced intentionality in social representation research', Journal for the Theory of Social Behaviour, vol. 24, no. 3, pp. 243-65.

Wagner, W 1998, 'Social representations and beyond: brute facts, symbolic coping and domesticated worlds', Culture and Psychology, vol. 4, no. 3, pp. 297-329.

Waterton, C \& Wynne, B 1999, 'Can focus groups access community views?', in R Barbour \& J Kitzinger (eds.), Developing focus groups research. Politics, theory and practice, Sage, London, pp. 127-43.

\begin{abstract}
About the Authors
Sabine Caillaud is an assistant professor of social psychology at the Institute of Psychology, University Paris Descartes. Her research focuses on the social representation approach and on collective emotions in a range of topic areas relating to environment and health issues. She is concerned with qualitative methodologies and, more specifically, with focus groups, narratives, and triangulation.
\end{abstract}

Nikos Kalampalikis is a full professor of social psychology at the Institute of Psychology, University Lyon 2, and director of the lab Social Psychology Research Group (GRePS, EA 4163). His main research is inspired by social representation's approach through applied projects, focusing on national identity, communication, names, gift, and beliefs. Furthermore, he has been dealing with qualitative methodologies, language, textual analysis, and the history of social psychology. 